\author{
(online) $=$ ISSN $2285-3642$ \\ ISSN-L = $2285-3642$ \\ Journal of Economic Development, Environment and People \\ Volume 9, Issue 1, 2020
}

URL: http://jedep.spiruharet.ro

e-mail: office jedep@spiruharet.ro

\title{
Perceptions regarding the quality of life among beneficiaries of home and residential care services
}

\author{
Mihaela Ghenţa ${ }^{1}$, Aniela Matei ${ }^{2}$, Luise Mladen-Macovel ${ }^{3}$, Elen-Silvana Bobârnat ${ }^{4}$ \\ 1,2,3,4 National Scientific Research Institute for Labour and Social Protection (INCSMPS), Romania
}

\begin{abstract}
The article aims to present the results of a qualitative research conducted among elderly persons (aged 65 years and more) who receive home and residential care in Romania. The research objectives were to collect perceptions with regard to the overall appreciation of the quality of life and the way the quality of services received influence elderly's image with regard to their own life. The scarcity of data on quality of life of dependent older persons recommended the use of qualitative methods. Data collection included ten semistructured interviews with beneficiaries of social and healthcare services. Findings show that the quality of life is a multidimensional concept, very often related to the health status, the level of autonomy, the social contacts, and the existence of a social support network. The results have implications for public policy makers, and supplement the knowledge with regard to the quality of life in older age.
\end{abstract}

Keywords: Older persons, social services, quality of care, quality of life;

\section{JEL Codes: J14, J17}

How to cite: GHENTA, Mihaela et al. Perceptions regarding the quality of life among beneficiaries of home and residential care services. Journal of Economic Development, Environment and People, [S.I.], v. 9, n. 1, p. 71-78, mar. 2020. ISSN 2285-3642. doi:http://dx.doi.org/10.26458/jedep.v9i1.658.

\section{Introduction}

Due to the increased longevity and life expectancy, quality of life has been an important topic for researchers working in the field of aging [1]. According to the World Health Organization (WHO), quality of life is a multidimensional concept that refers to the individual perception of one's own life, taking into account the values system and the cultural and social context, as well as the goals, expectations, standards and concerns of each person [2]. Research into the quality of life of older people can be categorized into two broad approaches [3]:

\footnotetext{
${ }^{1}$ Corresponding author: Tel.: + 403124069; E-mail address: ghenta@incsmps.ro
} 


\author{
(online) = ISSN $2285-3642$ \\ ISSN-L = $2285-3642$ \\ Journal of Economic Development, Environment and People \\ Volume 9, Issue 1, 2020 \\ URL: http://jedep.spiruharet.ro \\ e-mail: office jedep@spiruharet.ro
}

(a) classical gerontological researches that focus on "healthy aging" [4,5] - These research paradigms use as proxy indicators for the assessment of quality of life of the elderly, mainly, indicators related to the health status of elderly: functional capacity, psychological well-being, social support, morale, addiction, adaptation of a healthy life style; Moreover, this approach tends to homogenize older people, rather than recognize diversity and differences based on age, gender, race, etc.;

(b) holistic approaches based on recent methodologies which accept a multidimensional definition of the quality of life that encompasses several aspects of the elderly person's life. This can be measured by physical, mental, social, economic or other factors.

The approaches specific to social gerontology (part of holistic paradigm) start from the premise that old age is a social construct, and this has three important implications for research in the quality of life of the elderly. First, contrary to various stereotypes, the definition of good quality of life for the elderly is often similar to that identified for other age groups [6] although health (physical and mental) and functional capacity gain a much stronger focus, especially in old age [7]. Secondly, as human beings, the older persons have the right to determine their own meaning of quality of life. This means that they should be at the center of the process of measuring and defining quality of life. Although quality of life may decrease with an increase of the level of dependency, a number of studies show that older people who experience significant limitations in performing daily activities describe their quality of life as excellent [8]. Third, the quality of life of older people is influenced by both social and economic factors, as well as by individual and biological characteristics [9] or life history [10]. This underlines the crucial importance of the social structure and culture - race, gender, social class - in determining the life experiences of the elderly and their expectations of what it could be considered a good or less good quality of their life.

The aging process has different effects from one person to another, but studies of social gerontology show that the level of dependency is the most valid indicator for an adequate assessment of the problems faced by this age group. In this sense, the literature identifies five forms of dependency: (1) the economic dependency, that is due when the older person losses the active social role of producer of his own goods/services; (2) the physical dependency, that intervenes against the background of the existence of a disease/invalidity state; (3) mental dependency, determined by the progressive decline of the memory and the eventual establishment of the symptoms of dementia; (4) social dependency, resulting from the diminution of social roles played by the elderly and (5) emotional dependency.

\title{
2. Setting the context
}

Although the proportion of the population aged 65 and over in the total population is increasing $15.16 \%$ of the total population of the country in 2019 [11], the studies concerning the quality of life of the elderly are reduced at national level. As demographic projections regarding the evolution of this category of population indicate an increase in the share of the population aged 65 and over in total population up to $19.1 \%$ in 2020 , respectively $21.9 \%$ in 2030 [12], the social and mental well-being of these people becomes an important issue in Romania. Over a quarter (26.2\%) of the population over 75 years old and about $20 \%$ (16.2\%) of the population aged 65 and over, experienced a severe limitation in carrying out daily activities as a result of a health problem, in 2018 [12]. 


\author{
(online) $=$ ISSN $2285-3642$ \\ ISSN-L = $2285-3642$ \\ Journal of Economic Development, Environment and People \\ Volume 9, Issue 1, 2020
}

URL: http://jedep.spiruharet.ro

e-mail: office jedep@spiruharet.ro

Considering also the increase of the index of parental support (the share of the population of 80 years and over in total population aged 50-64 years) by about 6 pp during the period 2011-2019 (from 17.9\% in 2011 at $23.8 \%$ in 2019), it is to be expected that the elderly people will need more and more specialized support.

According to the legal framework (Law on social assistance no. 292/2011, with the subsequent modifications), any dependent person (who needs assistance for more than 60 days for carrying out the basic and instrumental activities of daily life) has the right to personal care services, granted according to the individual needs of assistance for fulfilling either the basic activities of daily life (ensuring body hygiene, clothing and dressing, feeding and hydration, transfer and mobilization, moving inside, communication etc.), or the instrumental activities of the daily life (food preparation, shopping, cleaning, travel abroad and accompanying, administration and management of goods, companionship and socialization).

The beneficiaries of the personal care services are the elderly, the disabled and the chronically ill, for whom the services are provided according to the degree of dependence (established on the basis of a national assessment grid).

The legal framework, respectively the National Strategy for Promoting Active Aging and Social Protection of the Elderly (2015-2020) recognizes the importance of making changes for this category of population from the perspective of: promoting different rehabilitation programs to favour an independent life; ensuring periodic data collection, monitoring and reporting on the long-term care system, making forecasts on the long-term care financing needs; carrying out periodic studies to monitor the social, behavioural and biomedical aspects of aging. In this context, the development of research tools in the area of assessing the quality of life of the elderly dependent persons is very important, developing the knowledge in the field and stimulating the implementation of evidence based policies.

In the context of the objectives regarding active aging and social protection of the elderly, including those beneficiaries of home and residential care services, political decisions need to be made [13]. The need to assess the social policies and services and to favour the most effective ones, as well as the interest for evidence-based policies is increasing. Themes like elder people in Romania and home and residential care services have been addressed in scientific research, but the quality of life of elderly beneficiaries of home and residential care services is a field of research that haven't been studied in Romania.

This article aims to provide tools for exploring the life of elderly in care service system and also to generate data for decisions-makers in the process of elaborating and selecting effective public policies for improving the life of elderly people in need for care.

\title{
3. Objective and method
}

Results presented in this article are part of an extended research concerning the quality of life of elderly people in Romania. The methods employed to attain this overall objective included a mixt of qualitative (interviews and focus-groups) and quantitative methods (questionnaire based survey), and a full description of the methods is about to be published. The present paper presents part of the qualitative research, namely the information collected through the semi-structured interviews conducted among the older dependent persons. Qualitative methods have been used as the study aimed to examine personal 


\author{
(online) = ISSN $2285-3642$ \\ ISSN-L = 2285 - 3642 \\ Journal of Economic Development, Environment and People \\ Volume 9, Issue 1, 2020 \\ URL: http://jedep.spiruharet.ro \\ e-mail: office jedep@spiruharet.ro
}

views, feeling and opinions from participants. Interviews were chosen not only to allow an exploration of their personal perceptions, attitudes and personal experiences, but also to enable the construction of the questionnaire applied in the second phase. The research contributes to the development of understanding and knowledge on the quality of life in old age, based on the beneficiaries of social services' views.

\title{
3.1. The structure of the interviews
}

The article presents perceptions of people aged 65 years and more with regard to their quality of life and the influence of care on this perceived image. In total, 10 semi-structured interviews with dependent older persons, beneficiaries of social services, were moderated.

To achieve a coherent view of the studied issue, the interviewees were chosen to cover beneficiaries of social services with accommodation (within the homes for the elderly, respite centers, protected dwellings) and without accommodation (provided by day care centers, recovery centers and home care units). The elderly persons included in this research are aged 65 years and over and discussions were conducted in the older persons' home/residential setting from Bucharest. The interview guide was developed by the team members, considering the previous scientific literature related to the topic.

\subsection{The data collection procedure and participants}

All interviews followed the same general structure, with an average duration of approximately 25-30 minutes. The themes of the semi-structured interviews were:

- The overall quality of life of the older dependents;

- Autonomy and independence, quality of care;

- Freedom of decisions, sense of control, trust and respect of intimacy;

- Communication, social relations;

- Living environment.

The interviews were held in May 2019 (May 15-23.05) and were audio recorded. The main characteristics of the participants are presented in the table below:

Table 1. The structure of the sample

\begin{tabular}{ccccc}
\hline Age & $\begin{array}{c}\text { Gender } \\
\text { (F/M) }\end{array}$ & $\begin{array}{c}\text { Type of social service } \\
\text { (Home care/Residential care) }\end{array}$ & $\begin{array}{c}\text { Supplier } \\
\text { (Public/Private) }\end{array}$ & $\begin{array}{c}\text { Children } \\
\text { (Y/N) }\end{array}$ \\
\hline $\begin{array}{c}\text { 75-79 years } \\
\text { old }\end{array}$ & $\mathrm{F}$ & Home care & Private & $\mathrm{Y}$ \\
\hline 80-84 years & $\mathrm{M}$ & Residential care & Public & $\mathrm{Y}$ \\
old & $\mathrm{M}$ & Home care & Private & $\mathrm{Y}$ \\
& $\mathrm{F}$ & Residential care & Public & $\mathrm{Y}$ \\
\hline 85 years and & $\mathrm{F}$ & Residential care & Public & $\mathrm{Y}$ \\
over & $\mathrm{F}$ & Rome care & Private & $\mathrm{N}$ \\
& $\mathrm{M}$ & Residential care & Public & $\mathrm{N}$ \\
& $\mathrm{F}$ & Home care & Public & $\mathrm{Y}$ \\
& $\mathrm{F}$ & Residential care & Public & $\mathrm{N}$ \\
& & & Public & $\mathrm{Y}$ \\
\hline
\end{tabular}




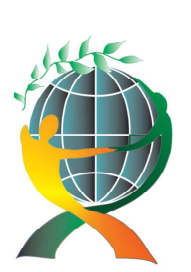

(online) = ISSN $2285-3642$

ISSN-L = $2285-3642$

Journal of Economic Development, Environment and People

Volume 9, Issue 1, 2020

URL: $\underline{\text { http://jedep.spiruharet.ro }}$

e-mail: office jedep@spiruharet.ro

\begin{tabular}{lllll} 
TOTAL & $7 / 3$ & $4 / 6$ & $7 / 3$ & $7 / 3$ \\
\hline
\end{tabular}

All of the respondents were widowers at the time of the discussion, suffered of multiple chronic diseases, and received both social and medical services.

\subsection{Overall appreciation concerning the quality of life}

Factors affecting the quality of life: Most often, the respondents named the health status, the limited level of autonomy, the reduced social contacts, and the absence of a social support network as the main factors that exert a major influence on the quality of life.

The level of perceived overall quality of life: Due to health problems, the quality of life is perceived as being poor, especially in the case of respondents receiving home care at the time of the research. The majority of respondents faced a limited movement capacity and this generates an intense dissatisfaction, reflected in poor relations with the live-in or non-live-in family members/residents. The overall feeling is that every aspect of life becomes difficult to control.

The physical illness, the movement difficulties change the perceived quality of life and contribute to the isolation of the older dependent persons, especially in case of the respondents receiving home care services. For those respondents in different residential settings, the nursing staff help them to move and to connect to other persons through different activities. With the exception of one person, those respondents that were in residential care mentioned the conflicts, the abandonment, and negligence in relation to family members. Respondents with good family relations reported a better emotional state, despite the physical health problems.

\subsection{Autonomy and independence, quality of care}

The life pace is influenced by the level of autonomy and independence: Most of the respondents have a precarious health condition that worsened due to limited access to professional services or at least a form of care. The inability to perform activities within the living space (home or residential units) and to care of him/herself is experienced as a shame and a feeling of culpability in relation to carers (family or professionals).

The access to quality care services is conditioned by the economic situation: The general perception in case of elderly receiving home care services is that access to services is depending on both access to information and the financial possibilities. Dependents often mentioned that they "don't know what services to access" or "don't have enough money to access services". In addition, the quality of care is related to the economic welfare of the elderly person or to the commitment of the family members to cover the necessary expenses. As a consequence, the general perception is that a good quality of care requires a high level of financial resources. Five out of six dependents in residential care acknowledge the good conditions they lived and being cared, as well as the evolution of the health status, after the internment in the retirement house.

\subsection{Freedom of choice, sense of control, trust and respect of intimacy}

Limited level of control: most of the decisions are taken by the family members. Discussions with home care beneficiaries, revealed that, in some cases, the burden of caring entitles the family to decide the 


\author{
(online) $=$ ISSN $2285-3642$ \\ ISSN-L = $2285-3642$ \\ Journal of Economic Development, Environment and People \\ Volume 9, Issue 1, 2020 \\ URL: http://jedep.spiruharet.ro \\ e-mail: office jedep@spiruharet.ro
}

provider, the type and the place of services, as well as with regard to the administration of the financial resources. At least one respondent in home care and almost all respondents in residential care mentioned a mixture of family members' conflicts and financial and moral issues as main reasons for assessing the care services/internment. In case of two respondents in residential care, the process of choosing the care provider was the result of consultations between the older persons and family members. Living in a family with multiple generations is sometime difficult and the burden of caregiving is a significant reason for institutionalizations. The level of control is limited to the daily activities - performing simple domestic duties, watching TV programs, reading books/newspapers.

The positive opinion with regard to the personal and services received is a constant in all respondents' views. The quality of the caregiver-cared for relationship is constantly indicated as a positive aspect of care services.

\title{
3.6. Communication and social relations
}

Limited social relations: Irrespectively with regard to the place of services, respondents mentioned the limited social relations. For those receiving services at home, disagreements with the family members is the main factor for loneliness, followed by the geographic distance. The data gathered revealed poor parentschildren relationships for the majority of respondents, irrespectively of gender and of provided services.

Communication with family members or with other friends, community members, volunteers (children or young persons) creates a positive spirit for the old person. Disagreements with family members, deterioration of relationships with children and grandchildren forced the decision to access residential services. An improvement in the quality of life can be determined, in the opinion of the most respondents, by carrying out several outdoor activities.

The respondents in residential care pointed that the frequency of socialization activities depends on the availability of human resources to ensure the implementation of such activities, the existence of an important event (religious holidays, etc.), and the health status of the beneficiaries. Activities that involve interaction between generations are most appreciated by the elderly residents. Such activities create a good mood and contribute to emotional balance. In the case of the elderly in home care, the loneliness and the lack of accessibility of the living space (house/building, neighborhood), are felt with acuity.

\subsection{Living environment}

The importance of the living environment is essential, as it could facilitate or harm the independence and communication, the social interaction. The inaccessibility of the home/building is perceived as an obstacle for an independent life especially in case of the respondents in home care. Some of the respondents (in home care and ibn residential care as well) home care felt very nostalgic with regard to the homes they were used to live in for years and associated them with freedom, happy memories.

\section{Conclusions}

The aim of this article was to give an insight into the quality of life of elderly persons receiving home and residential care in Romania. The concept of the quality of life incorporated several domains important 


\author{
(online) $=$ ISSN $2285-3642$ \\ ISSN-L = $2285-3642$ \\ Journal of Economic Development, Environment and People \\ Volume 9, Issue 1, 2020
}

URL: http://jedep.spiruharet.ro
e-mail: $\underline{\text { office jedep@spiruharet.ro }}$

from the perspective of a dependent person. By examining older persons' perceptions, this paper provide a picture of the quality of life of older dependents.

Previous studies $[14,15$, and 16] revealed the same complexity of the concept and the multiple dimensions that has to be considered in relation to older persons. Based on the conclusions of this study, the limited level of autonomy and the physical health condition are the main factors that affect the everyday life and the perceived quality of life, results consistent with other researches [14, 16].

The low level of available incomes (pensions) hinder the access to care, as the monthly costs of care must be partially covered by the older persons. Participants to this study turn to family members to cover the access to essential care services. Economic costs of care are high and affects negatively the quality of life in old age. Social participation, intergenerational family relationships, availability of friends and social support networks are important determinants of the quality of life in old age. Social contacts were frequently associated with high quality of life indices among the elderly. Empirical research has shown that there are strong associations between social support, social network structure and issues that take into account mortality, mental and physical health, but also the general well-being of the elderly $[17,18]$. There are also empirically demonstrated associations between social participation and /or support and feelings of security, self-esteem and, therefore, self-control [19]. Attitudes of care staff contribute to the feeling of support and security expressed by the interviewees.

The results are consistent with previous studies [14] that revealed the same importance of the living environment for a good quality of life in old age and the impact of green outdoor space on the quality of life of older persons living in different care facilities [20]. Housing/building issues were often mentioned as being implicated in caring activities. Internment of the older person is, in some cases, the only solution, but, as a half of the respondents in residential care mentioned, it has a high cost both emotionally and economically. The physical environment is an important context and a major determinant of the quality of life of the elderly. In the case of the elderly in residential care, the physical environment influences aspects of quality of life such as: comfort, safety and security, nutrition, social relations, autonomy, independence. Older people who live in a community where they have a sense of security, have good relations with neighbours, access to green spaces or good local facilities (shops, markets, post offices, etc.) experience a better quality of life. Access to means of transport was considered important in maintaining social contacts, independence [14].

\title{
5. Acknowledgements
}

This work was published under the Research and development plan of the Ministry of Labour and Social Justice for 2018 - 2020, contract no. 3676/28.09.2018 (Această lucrare a fost realizată prin Planul sectorial de cercetare - dezvoltare al Ministerului Muncii și Justiției Sociale pentru perioada 2018 - 2020, contract nr. 3676/28.09.2018, proiect cu titlul “Calitatea vieţii persoanelor vârstnice dependente în România").

\section{References}

[1] S. Hall, D. Opio, R.H. Dodd, J.J. Higginson. Assessing quality-of-life in older people in care homes. Age Ageing, 40(4), 507-512, 2011. 


\author{
(online) = ISSN $2285-3642$ \\ ISSN-L = $2285-3642$ \\ Journal of Economic Development, Environment and People \\ Volume 9, Issue 1, 2020 \\ URL: http://jedep.spiruharet.ro \\ e-mail: office jedep@spiruharet.ro
}

[2] WHOQOL Group. Development of the World Health Organization WHOQOL-BREF Quality of Life Assessment. Psychological Medicine, 28, 551-558, 1998.

[3] A. Walker. A European perspective on quality of life in old age. European Journal of Ageing, 2(1), 2-12, 2005.

[4] P.B. Baltes. The aging mind: potential and limits. The Gerontologist, 33(5), 580-94, 1993.

[5] J.W. Rowe, R.L. Kahn. Successful ageing. The Gerontologist, 37(4), 433-440, 1997.

[6] J. Bond. Quality of life for people with dementia: approaches to the challenge of measurement. Ageing Society, 19(5), 561-579, 1999.

[7] G. Netuveli, D. Blane. Quality of life in older ages. British Medical Bulletin, 85(1), 113-126, 2008.

[8] A. Bowling, J. Barber, R. Morris, S. Ebrahim. Do perceptions of neighbourhood environment influence health? Baseline findings from a British survey of aging. Journal of Epidemiology and Community Health, 60, 476-483, 2006.

[9] A. Walker. Toward a political economy of old age. Ageing and Society, 1, 73-94, 1981.

[10] J. B. Morganti, M. F Nehrke, I. M. Hulicka, J. F. Cataldo. Life-span differences in life satisfaction, self-concept, and locus of control. International Journal of Aging and Human Development, 26(1), 45-56, 1988.

[11] National Institute of Statistics, www. insse.ro, 2020.

[12] Eurostat, https://ec.europa.eu/eurostat/home, 2020.

[13] European Commission. Towards Social Investment for Growth and Cohesion - including implementing the European Social Fund 2014-2020, 2013.

[14] N. Gabriel, A. Bowling, A. Quality of life from the perspectives of older people. Ageing \& Society, 24, 675-691, 2004.

[15] P. Teofilou. Quality of Life: Definition and Measurement. Europe's Journal of Psychology, Vol. 9(1), 150-162, 2013.

[16] N. Dorji, M.P. Dunne, C. Seib, S. Deb. Qualitative Inquiry into Quality of Life among Older Adults in Bhutan. Biomedical Journal of Scientific and Technical Research, 5(4), 4736-4743, 2018.

[17] A. Bowling. Social networks and support among older people and implications for emotional well-being and psychiatric morbidity. International Review of Psychiatry, 9, 447-459, 1994.

[18] A. Bowling, E. Grundy. Longitudinal studies of social networks and mortality in later life. Review in Clinical Gerontology, 8, 353-361, 1998.

[19] G.C. Wenger. Morale in old age: A review of the evidence. International Journal of Geriatric Psychiatry, 7, 699-708, 1992.

[20] M. Artmann, X. Chen, C. Ioja, A. Hofd, D. Onosec, L. Poniżye, A. Zavodnik Lamovšekf, J. Breusted. The role of urban green spaces in care facilities for elderly people across European cities. Urban Forestry \& Urban Greening, vol. 27, 203-213, 2017. 